JPPUMA: Jurnal Ilmu Pemerintahan dan Sosial Politik UMA, Uournal of Governance and Political Social UMA), 7 (1) (2019): 1- 11

JPPUMA: Jurnal Ilmu Pemerintahan dan Sosial Politik UMA

(Journal of Governance and Political Social UMA)

DOI: http://dx.doi.org/10.31289/ippuma.v7i1.2021

Available online http://ojs.uma.ac.id/index.php/jppuma

\title{
Relasi Demokrasi, Kekuasaan, dan Politik Hukum dalam Pemilihan Presiden dan Wakil Presiden Tahun 2019
}

\section{The Relationship of Democracy, Power, and Politics of Law in the Election of the President and Vice President in 2019}

\author{
M. Luthfi Munzir A.M. Burhani1)*, Jendrius²), Syahrizal ${ }^{3)}$ \\ 1) Jurusan Konsentrasi Tata Kelola Pemilu Fakultas Ilmu Sosial dan Ilmu Politik Universitas \\ Andalas, Indonesia \\ 2) Jurusan Sosiologi, Fakultas Ilmu Sosial dan Ilmu Politik Universitas Andalas, Indonesia \\ 3) Jurusan Antropologi, Fakultas Ilmu Sosial dan Ilmu Politik, Universitas Andalas, Indonesia
}

Diterima: November 2018; Disetujui: Februari 2019; Dipublish: Juni 2019

\begin{abstract}
Abstrak
Pemilihan Umum merupakan sarana kedaulatan rakyat yang diselenggarakan secara langsung, umum, bebas, rahasia, jujur, dan adil (luber dan jurdil). Undang-Undang Nomor 7 Tahun 2017 tentang Pemilihan Umum sebagai produk politik hukum justru tidak menempatkan para kandidat yang akan bertarung dalam Pemilihan Presiden dan Wakil Presiden Tahun 2019 dalam posisi yang adil dan setara. Petahana lebih diuntungkan sehingga menimbulkan ambigu kepentingan. Keadilan substansial sebagai bagian dari demokrasi yang sesungguhnya cenderung diabaikan demi kekuasaan. Tulisan ini menggunakan pendekatan studi literatur. Bias kepentingan tersebut bisa dihindari dengan menempatkan regulasi dengan setara dan adil. Perlu ada revisi terhadap UU No.7 Tahun 2017 sehingga petahana yang akan mencalonkan diri kembali sebagai capres atau cawapres mengundurkan diri dari jabatannya. Hal ini untuk menjaga asas keadilan dalam proses pemilu 2019 dan menjaga agar ambigu kepentingan tidak digunakan untuk memperoleh kekuasaan.
\end{abstract}

Kata Kunci: Relasi Demokrasi, Kekuasaan, Politik Hukum

\begin{abstract}
General Election is a means of popular sovereignty that is held directly, publicly, freely, secretly, honestly and fairly (overflowing and fair). Law Number 7 of 2017 concerning General Elections as a product of legal politics does not place candidates who will fight in the Election of President and Vice President in 2019 in a fair and equal position. Incumbents benefit more so that they create ambiguous interests. Thus, substantial justice as part of real democracy tends to be ignored for the sake of power. This paper uses a literature study approach. This interest bias can be avoided by placing regulations equally and fairly. There needs to be a revision of Law No.7 of 2017 so that the incumbent who will run again as a presidential candidate or vice president resigns from his position. This is to safeguard the principle of justice in the 2019 electoral process and to keep ambiguous interests from being used to gain power.
\end{abstract}

Keywords: Relationship of Democracy, Power, Politics of Law

How to Cite: Burhani, M.M.A.M. Jendrius, \& Syahrizal. (2019) Relasi Demokrasi, Kekuasaan, dan Politik Hukum dalam Pemilihan Presiden dan Wakil Presiden Tahun 2019, JPPUMA: Jurnal Ilmu Pemerintahan dan Sosial Politik UMA, (Journal of Governance and Political Social UMA), 7 (1) (2019): 1- 11

${ }^{*}$ Corresponding author:

E-mail: m.luthfimunzir@gmail.com
ISSN 2549-1660 (Print)

ISSN 2550-1305 (Online) 


\section{PENDAHULUAN}

Pemilihan Umum tahun 2019 merupakan sejarah baru dalam demokrasi prosedural dan elektoral di Indonesia. Untuk pertama kalinya, pemilihan umum untuk memilih anggota DPR, DPD, DPRD Provinsi dan DPRD Kabupaten/Kota dengan pemilihan umum Presiden dan Wakil Presiden dilaksanakan serentak, 17 April 2019. Artinya, pemilu 2019 akan semakin kompleks dan melelahkan. Tidak saja kompleks dan melelahkan oleh Komisi Pemilihan Umum dan Badan Pengawas Pemilu sebagai penyelenggara pemilu, tetapi juga bagi peserta pemilu, seperti partai politik, calon anggota legislatif, calon anggota Dewan Perwakilan Daerah (DPD), maupun calon Presiden dan Wakil Presiden. Khusus untuk pemilu Presiden dan Wakil Presiden menjadi pusat perhatian rakyat karena hanya ada dua pasangan calon yang akan berkontestasi, yaitu pasangan Joko Widodo-KH.Ma'ruf Amin dan Prabowo Subianto-Sandiaga Uno.

Dua pasangan calon ini muncul sebagai bagian dari dinamika politik nasional yang sangat alot. Joko Widodo merupakan petahana yang diusung oleh tujuh partai politik, yaitu Partai Demokrasi Indonesia Perjuangan (PDIP), Golkar, Partai Kebangkitan Bangsa (PKB), Partai Persatuan Pembangunan (PPP), Nasdem, Hanura, dan Partai Keadilan dan Persatuan Indonesia (PKPI). Saat tahapan pendaftaran calon presiden dan wakil presiden (tanggal 4 sampai 10 Agustus 2018) Joko Widodo masih menjabat sebagai Presiden RI periode 2014-2019. Sementara Prabowo Subianto adalah Ketua Umum Partai Gerindra yang diusung oleh empat partai politik, yaitu Gerindra, Partai Keadilan Sejahtera (PKS), Partai Amanat Nasional (PAN), dan Demokrat. Pada Pemilu 2014, Prabowo juga menjadi penantang Joko Widodo meski dengan calon wakil presiden yang berbeda. Pemilihan Presiden dan Wakil Presiden 2019 juga disebut-sebut sebagai rematch politik 2014. (Rahadian, 2018, Inilah Peta Partai Pengusung Capres dan Cawapres Pemilu 2019, https://www.cnbcindone sia.com/news/20180810195720-16-2808 7/inilah-peta partai-pengusung-capres-ca wapres pemilu-2019, diakses tanggal 12 Oktober 2018).

Terbatasnya calon pemimpin Indonesia yang muncul sebagai kandidat adalah realitas demokrasi Indonesia yang mencerminkan dominasi politik elite, dan politik hukum yang dikonstruksi secara legal-formal untuk menghambat nilai-nilai demokrasi hakiki. Undang-Undang Dasar RI Tahun 1945 Pasal 6A menyebutkan bahwa pasangan calon presiden dan wakil presiden diusulkan oleh partai politik atau gabungan partai politik peserta pemilihan umum sebelum pelaksanaan pemilihan umum. Tidak ada ruang bagi kandidat yang berasal dari calon perseorangan atau tanpa melalui partai politik untuk menjadi calon presiden dan wakil presiden. Secara langsung atau tidak, pembatasan melalui partai politik mencerminkan bahwa hanya kepentingan partai politik yang berkuasa dan membatasi hak-hak konstitusional warga negara untuk turut serta dalam pemerintahan. Permohonan calon presiden independen sebenarnya pernah diajukan ke Mahkamah Konstitusi (MK) oleh Fadjoel Rahman cs dengan permohonan pengujian Pasal 1 angka 4, Pasal 8, Pasal 9, dan Pasal 13 ayat (1) UndangUndang Nomor 42 Tahun 2008 tentang Pemilihan Umum Presiden dan Wakil Presiden. Hakim MK ketika itu menolak seluruh permohonan pemohon karena bertentangan dengan UUD RI Tahun 1945 Pasal 6A. (Ali, 2009, MK Tolak Permohonan Capres Independen, https://ww w.hukumonline.com/berita/baca/hol2121 6/mk-tolak-permohonan-capres-indepen den, diakses 12 Oktober 2018).

UUD RI Tahun 1945 maupun UU Nomor 7 Tahun 2017 tentang Pemilihan Umum tidak memuat klausual tentang mekanisme yang demokratis dan adil bagi semua pihak yang tengah berkontestasi. 
Presiden yang sedang berkuasa dan mencalonkan diri kembali pada periode berikutnya atau biasa disebut dengan istilah petahana, dalam konteks demokrasi berada pada pihak yang paling diuntungkan dibandingkan dengan kandidat lain. Calon dari petahana mempunyai waktu yang sangat panjang untuk bersosialisasi dengan rakyat, termasuk "kampanye" politik melalui programprogram pemerintah yang dipimpinnya. Seringkali petahana memanfaatkan dua momentum sekaligus; sebagai pemimpin negara dan sebagai calon Presiden dan Wakil Presiden. Pada posisi seperti itu, rakyat sulit untuk membedakan peran tersebut, apakah sedang menjalankan program kerjanya atau berkampanye? Atau kedua-duanya sekaligus? Maka kampanye tanpa berkampanye menjadi kalimat yang pas bagi calon petahana.

Beberapa contoh bias kebijakan pemerintah yang rentan dikaitkan dengan aspek politik atau kampanye calon dari petahana, antara lain: kebijakan kenaikan bahan bakar minyak jenis premium yang rencananya akan diberlakukan pada Hari Rabu 10 Oktober 2018 mulai Jam 18.00 WIB tidak jadi dinaikkan. Padahal, satu jam sebelumnya sudah ada pengumuman dari Menteri Energi dan Sumber Daya Mineral (ESDM) Ignasius Jonan terkait tentang tarif baru Bahan Bakar Minyak (BBM) jenis premium. Penundaan kenaikan premium tersebut karena Presiden Joko Widodo mempertimbangkan daya beli masyarakat. (Purnamasari, 2018, Jokowi Buka Suara Soal Harga Premium yang Batal Naik, https://finance.detik.com/energi/d-4254 994/jokowi-buka-suara-soal-harga-premi um-yang-batal-naik, diakses 14 Oktober 2018). Langsung atau tidak,hal ini tentu saja akan dikaitkan dengan aspek politik yang lebih dipertimbangkan oleh calon dari petahana dibandingkan aspek ekonomi. Apabila BBM bersubsidi dinaikkan di tahun politik, sedikit atau banyak akan berpengaruh kepada tingkat keper cayaan rakyat kepada calon dari petahana. Ini tentu kebijakan yang tidak populis dan beresiko secara politis.

Contoh kedua, terbongkarnya kebohongan yang dilakukan aktivis perempuan Ratna Sarumpaet yang berim bas ke ranah politik. Akar masalahnya sederhana; kebohongan pertama untuk menutup kebena ran dari keluarganya. Ketika calon Presiden Prabowo Subianto mengetahui dari sumber primer secara langsung, Selasa 26 September 2018, Prabowo dan tim sukses mengadakan konferensi pers yang diliput media untuk menyatakan keprihatinannya dan meminta pemerintah agar mengusut tuntas pelakunya. Pada akhirnya, ketika pernya taan dari sumber primer tersebut diakui sendiri oleh sumbernya sebagai suatu kebohongan, tim sukses calon Presiden Prabowo Subianto ikut terseret kasus hoax tersebut.

Contoh ketiga, gerakan tagar \#2019gantipresiden yang dianggap pihak istana presiden sebagai bagian dari makar dan inkonstitusional sehingga gerakan tersebut harus dihentikan (Fazli, 2018, Istana Sebut Gerakan 2019 Ganti Presiden Makar, http://news.metrotvnews.com/hu kum/Gbmj1nyk-istana-sebut-gerakan-201 9-ganti-presiden-makar, diakses 14 Okto ber 2018). Meski Badan Pengawas Pemilu (Bawaslu) menilai gerakan \#2019ganti presiden maupun \#Jokowi2periode bukan bagian dari kampanye (Ekarista R.P, 2018, Bawaslu: Gerakan '2019 Ganti Presiden' dan 'Jokowi 2 Periode' Tak Bisa Disebut Aktivitas Kampanye, http://kaltim.tribun news.com/2018/08/31/bawaslu-gerakan2019-ganti-presiden-dan-jokowi-2-perio de-tak-bisa-disebut-aktivitas-kampanye, di akses 14 Oktober 2018). Gelombang penolakan gerakan \#2019gantipresiden tersebut dilakukan di sejumlah daerah. Para aktornya diperiksa dan dilarang untuk mendeklarasikan gerakan tersebut. Di media sosial, "perang" antar kubu pendukung calon Presiden dan Wakil Presiden tidak terhindarkan. Saling ejek, fitnah, dan komentar-komentar "menye rang" tidak terhindarkan. Sementara itu, sepuluh 
kepala daerah di Provinsi Sumatera Barat mendeklarasikan du kungan kepada calon petahana Joko Widodo, Selasa (18/09/ 2018). Mereka menilai besarnya perhatian dan keber hasilan Joko Widodo ke Sumatera Barat (Rahmadhani, 2018, 10 Kepala Daerah di Sumbar Deklarasi Dukung Jokowi, https://regional.kompas.com/re ad/2018/09/19/08113981/10-kepala-da erah-di-sumbar-deklarasi-dukung-jokowi, diakses 14 Oktober 2018). Bila dilihat dari jadwal tahapan kampanye berdasarkan Peraturan Komisi Pemilihan Umum Nomor 32 Tahun 2018, masa kampanye baru dimulai tanggal 23 September 2018 sampai 13 April 2019. Akan tetapi, deklarasi sejumlah kepala daerah tersebut tidak disebut sebagai bagian dari sebuah pelanggaran.

Contoh keempat, beberapa waktu lalu Indonesia dilanda gempa silih berganti. Terparah di Lombok Nusa Tenggara Barat dan Sigi, Pagu, dan Donggala di Sulawesi Tengah (gempa yang diikuti dengan tsunami). Pemerintah berusaha dengan cepat memberikan pertolongan dan bantuan. Di tahun politik, bantuan dan pertolongan tersebut bisa menjadi bias dan bisa ditunggangi kepentingan politik tertentu.

Empat contoh di atas menggambarkan realita biasnya peran dan fungsi calon dari petahana, antara tugas dan tanggung jawabnya sebagai presiden yang sedang berkuasa, sekaligus sebagai calon presiden yang akan bertarung kembali di Pemilu 2019. Di sisi lain, kelompok penantang calon dari petahana berada dalam ruang gerak yang sempit. Salah melangkah bisa dituding oleh lawan politik yang tengah berkuasa sebagai pelanggaran hukum. Oleh penguasa, calon penantang bisa dianggap melakukan tindakan inkonstitusional apabila dianggap membaha yakan negara dan kekuasaan yang sedang dijalankannya. Pada posisi itulah sesungguhnya calon petahana berada pada ruang yang dilematis, sekaligus menguntungkan secara politis.
Kekuasaan seringkali digunakan untuk kepentingan politik kelompok tertentu. Alih-alih untuk kepentingan masyarakat, dan menjunjung keadilan substansial, kekuasaan cenderung bertujuan untuk mengendalikan kelompok tertentu dalam masyarakat, agar tunduk kepada pemegang kekuasaan tersebut. Sejalan dengan konsep pemilihan umum sebagai instrumen demokrasi dan kaitannya dengan politik hukum dalam upaya mempertahankan dan/ atau meraih kekuasaan dalam pemilu Presiden dan Wakil Presiden Tahun 2019, menarik untuk dilihat relasi demokrasi dengan ketimpangan kekuasaan yang dimiliki oleh masing-masing kandidat. Joko Widodo sebagai Presiden petahana sekaligus calon Presiden RI 2019-2024 dengan Prabowo Subianto sebagai rakyat sekaligus calon Presiden RI 2019-2024. Apakah stratifikasi politik kedua pasangan kandidat tersebut berjalan secara demokratis? Atau politik hukum yang bermuara pada produk hukum secara legal dan konstitusional justru belum memberikan nilai-nilai demokrasi yang hakiki? Tulisan ini menjelaskan gambaran tentang hal tersebut. Sekaligus menimbang bagaimana secara demokratis harus menempatkan dua pasangan calon Presiden dan Wakil Presiden RI 2019-2024.

\section{METODE PENELITIAN}

Penelitian ini menggunakan studi pustaka. Studi kepustakaan dapat mempelajari berbagai referensi serta hasil penelitian sebelumnya yang sejenis berguna untuk mendapatkan landasan teori mengenai masalah yang akan diteliti (Sarwono, 2016). Studi kepustakaan dilakukan dalam penelitian ini dengan mengumpulkan data serta melakukan penelaahan terhadap dokumen-dokumen serta laporan yang berkaitan dengan tema tulisan.

Proses penelitian kepustakaan dilakukan dengan melakukan pemilihan topik berdasarkan fenomena yang sedang 
terjadi, kemudian mencari informasi sebagai basis data yang berasal dari buku, jurnal dan sumber internet terkait dengan topik tersebut, menganalisisnya dan mengkonstruksikan serta menyajikannya dalam bentuk tulisan ilmiah.

\section{HASIL DAN PEMBAHASAN}

Demokrasi mempunyai ruang lingkup yang sangat luas, sehingga bisa didefiniskan dalam banyak terminologi. Meski, konsep demokrasi secara umum seperti dikemukakan Presiden Amerika Serikat Abraham Lincoln (1809-1865) yang mendefinisikan demokrasi sebagai: Government of the people, by the people, for the people. Demokrasi sebagai pemerintahan dari rakyat, oleh rakyat, dan untuk rakyat (Muhadam \& Ilham, 2017). Hakikat demokrasi adalah kemanfaatan dengan sebesar-besarnya segala bentuk kebijakan untuk kepentingan rakyat.

David Baetham dan Kevin Boyle (2000) melihat demokrasi dalam dua hal penting, pertama; demokrasi merupakan perwujudan keinginan secara keseluruhan anggota, dan setiap anggota mempunyai hak yang sama; kedua, adanya partisipasi rakyat dalam mengontrol kesetaraan politis tersebut. (Mufti, 2013). Dalam pandangan ini konsep demokrasi berada dalam posisi yang memungkinkan tidak adanya marginalitas antara satu kandidat dengan kandidat yang lain, atau antara individu yang satu dengan individu yang lain sebagai bagian dari rakyat guna mengontrol terwujudnya kesetaraan secara politis. Kesempatan yang sama untuk memilih dan dipilih serta berperilaku politis dalam bentuk - bentuk kegiatan politik yang setara atau seimbang.

Pandangan lain dari para ahli tentang definisi demokrasi seperti dikemukakan William Ebenstein dalam (Mufti \& Naafisah, 2013) mendefinisikan demokrasi dengan menyebutkan kriteria demokrasi, yaitu: (1) empirisme rasional; (2) penekanan pada individu; (3) negara sebagai alat; (4) kesukarelaan (voluntarism); (5) hukum di atas kekuasaan; (6) penekanan pada cara; (7) musyawarah dan mufakat dalam hubungan antarmanusia; (8) persamaan asasi semua manusia.

Sejalan dengan itu, Hendry B. Mayo dalam (Budiardjo, 2004) menggambarkan demokrasi ke dalam enam kriteria, yaitu: (1) menyelesaikan perselisihan secara damai dan sukarela; (2) menjamin terselenggaranya perubahan secara damai dalam masyarakat yang sedang berubah; (3) menyelenggarakan pergantian pimpinan secara teratur; (4) membatasi penggunaan kekerasan secara minimum; (5) adanya keragaman; (6) tercapainya keadilan.

Sementara menurut Juan J. Linz dan Alfred Stepan (1996) dalam Journal of Democracy berjudul Toward Consolidated Democraties menggambarkan transisi yang demokratis ketika prosedur politik untuk menghasilkan pemerintah terpilih, ketika pemerintah berkuasa hasil pemilihan umum secara langsung secara bebas, ketika pemerintah ini secara de facto memiliki wewenang untuk menghasilkan kebijakan baru, dan ketika kekuasaan eksekutif, legislatif dan yudisial dihasilkan oleh demokrasi baru yang tidak harus berbagi kekuasaan dengan badan-badan lain secara de jure". (Linz \& Stepan, 1996). Pandangan Juan J. Linz dan Alfred Stepan ini menggambarkan bahwa demokrasi memerlukan suatu mekanisme atau instrumen pembagian kekuasaan yang pada akhirnya dilakukan melalui pemilihan umum.

Sehingga dengan demikian bisa digambarkan bahwa demokrasi memiliki definisi yang luas dan beragam, tergantung dari aspek mana menilai demokrasi. Dalam tulisan ini, konsep demokrasi pada akhirnya dimaknai sebagai upaya yang dilakukan oleh seseorang atau sekelompok orang untuk memperoleh kekuasaan dengan cara legal-formal sesuai aturan yang berlaku, mengutamakan jalan damai, persatuan dan kesatuan bangsa, menjunjung tinggi hak asasi manusia, kesetaraan 
secara politis, dan merangkul keterlibatan seluruh komponen atau kelompok masyarakat yang majemuk dalam proses pergan tian kepemimpinan demi terwujudnya kesejahteraan dan keadilan bagi rakyat.

Konsep politik hukum adalah kebijakan penyelenggara negara yang bersifat mendasar dalam menentukan arah, bentuk maupun isi daripada hukum yang akan dibentuk dan tentang apa yang dijadikan kriteria untuk menghukumkan sesuatu. Dengan demikian, politik hukum berkaitan dengan hukum yang berlaku di masa yang akan datang (ius constituendum). Dimaksudkan sebagai da- sar di dalam implementasi konstitusional sebagaimana diatur dalam UUD 1945 (Wahidin, 2017).

Menurut Mahfud MD politik hukum adalah legal policy yang akan atau telah dilaksanakan secara nasional oleh pemerintah Indonesia. Politik hukum juga mencakup tentang bagaimana politik memengaruhi hukum dengan cara melihat konfigurasi kekuatan yang ada di belakang pembuatan dan penegakan hukum itu (Mahfud MD, 2017). Pengertian lain politik hukum seperti yang dikemukakan Padmo Wahjono dalam (Wahidin, 2017) yang mendefinisikan "politik hukum sebagai kebijakan dasar yang menentukan arah, bentuk maupun isi hukum yang akan dibentuk". Sehingga, di dalam politik hukum ada tujuan yang hendak dicapai dari pembentukan kebijakan yang dibuat secara konstitusional yang tidak terlepas dari kepentingan-kepentingan politik.

Hukum memberikan dasar legalitas bagi kekuasaan politik dan kekuasaan politik membuat hukum menjadi lebih efektif. Dengan kata lain, hukum adalah kekuasaan yang diam dan politik adalah hukum yang in action dan kehadirannya dirasakan serta berpengaruh pada kehidupan kemasyarakatan. (Hajati, Winar si, Sekarmadji, \& Moechthar, 2017)

Pandangan lain tentang politik hukum dikemukakan Satjipto Rahardjo (dalam Wahidin, 2017, p. 25) mendefinisikan politik hukum sebagai aktivitas memilih dan cara yang hendak dipakai untuk mencapai suatu tujuan sosial dan hukum tertentu dalam masyarakat. Pada hubungan ini lebih menitikberatkan pada proses yang hakikatnya secara sosial mengarahkan pada tercapainya tujuan negara sebagaimana disebutkan dalam konsti tusi. Sedangkan Sunaryati Hartono dalam (Wahidin, 2017) mendefi- nisikan politik hukum secara eksplisif. Politik hukum sebagai sebuah alat (tool) atau sarana dan langkah yang dapat digunakan pemerintah untuk menciptakan sistem hukum nasional yang dikehendaki dan dengan sistem hukum nasional itu akan diwujudkan cita-cita bangsa Indonesia.

Sehingga dengan demikian, konsepsi demokrasi dan politik hukum didefinisikan sebagai upaya yang dilakukan oleh seseorang atau sekelompok orang untuk memperoleh kekuasaan dengan cara legalformal sesuai aturan yang berlaku, mengutamakan jalan damai, persatuan dan kesatuan bangsa, menjunjung tinggi hak asasi manusia, dan merangkul keterlibatan seluruh komponen masyarakat yang majemuk dalam proses pergantian kepemimpinan melalui suatu legal policy mengenai pembangunan hukum demi terwujudnya kesejahteraan dan keadilan bagi rakyat.

Sementara itu kekuasaan didefinisikan sebagai kemampuan seseorang atau sekelompok orang untuk mempengaruhi tingkah lakunya seseorang atau kelompok lain sedemikian rupa sehingga tingkah laku itu menjadi sesuai dengan keinginan dan tujuan dari orang yang mempunyai kekuasaan itu. (Budiardjo, 2004). Robert M. Max Iver dalam (Budiardjo, 2004) mengatakan bahwa kekuasaan adalah kemampuan untuk mengendalikan tingkah laku orang lain, baik secara langsung dengan jalan memberi perintah maupun secara tidak langsung dengan mempergunakan segala alat dan cara yang tersedia. Dalam pandangan Max Weber (1947) dalam 
(Mufti, 2013, p. 55), salah satu bentuk kekuasaan adalah kekuasaan legal-formal. Artinya kekuasaan yang ada dan sah serta dibuat melalui mekanisme yang konstitusional sehingga berdasarkan hal tersebut seperangkat peraturan perundang-undangan secara resmi dan diatur secara impersonal. Sehingga dengan demikian setiap orang harus tunduk dan patuh kepada kekuasaan legal-formal tersebut, karena peraturan yang membuat seseorang untuk patuh, bukan karena kekuasaan yang dimiliki oleh seseorang atau sekelompok orang.

Kekuasaan yang terwujud dalam negara seperti Presiden dilaksanakan dengan menjalankan perintah UUD 1945 dan Undang-Undang. Tujuan dibuatnya regulasi atau aturan hukum adalah untuk mengatur seseorang, sekelompok orang dan/ atau seluruh rakyat agar tunduk pada aturan yang disetujui bersama sebagaimana yang disebut Jean Jacques Rousseau sebagai kontrak sosial. Dalam konteks pemilihan umum Presiden dan Wakil Presiden, regulasi di Indonesia mengatur bahwa Presiden yang kembali mencalonkan diri untuk periode kedua atau disebut calon petahana tidak harus mengundurkan diri dari jabatannya sebagai Presiden. Artinya, selain sebagai Presiden untuk menghabiskan masa jabatannya di periode pertama, sejak ditetapkan sebagai calon Presiden atau Wakil Presiden oleh Komisi Pemilihan Umum RI untuk masa jabatan periode kedua, yang bersangkutan menyandang dua peran sekaligus; sebagai Presiden atau Wakil Presiden di periode pertama dan sebagai calon Presiden atau Wakil Presiden menuju periode kedua.

Politik hukum di Indonesia mengatur hal yang demikian, tetapi apabila dikembalikan kepada konsep demokrasi, dalam pengertian perlakuan yang setara secara politis, maka regulasi di Indonesia cenderung mengutamakan kepentingan elite penguasa. Setiap pasangan calon Presiden dan Wakil Presiden tidak ditempatkan pada posisi yang sejajar, setara, dan sama dalam kontestasi politik. Calon petahana cenderung lebih diuntungkan oleh regulasi yang merupakan produk politik yang kemudian dilegitimasi secara konstitusional. Beberapa contoh yang telah dikemukakan di bagian pendahuluan adalah pola yang sangat mungkin dilakukan calon petahana dalam dua posisinya secara bersamaan. Termasuk memanfaatkan fasilitas negara secara terselubung untuk kepentingan politik pragmatis yang sulit untuk dipastikan. Siapa yang dapat mengawasi dan memastikan bahwa calon petahana tidak berada pada bias kepentingan tersebut?

Keistimewaan dalam regulasi hukum di Indonesia pada sejumlah pejabat negara menggambarkan bahwa ia sah sebagai produk politik hukum yang lahir dari proses yang demokratis, tetapi secara substansial regulasi seperti itu justru mengadopsi nilai-nilai yang tidak demokratis, semacam oligarki yang dikemukakan Aristoteles (384-322 SM) sebagai konsep yang mengabaikan kepentingan umum dan cenderung hanya untuk kepentingan kelompok yang berkuasa (Budiyanto, 2003). Dalam konteks demokrasi melalui pemilihan umum secara langsung, hal ini sangat berbahaya karena penguasa memiliki otoritas yang tinggi dibandingkan dengan kelompok lain. Penguasa yang sedang berkuasa dan pada waktu yang bersamaan mencalonkan diri kembali untuk berkuasa untuk kedua kalinya rentan dengan penyalahgunaan kekuasaan dan kewenangan.

Dalam jurnal berjudul Demokrasi dan Kekuasaan Politik Calon Incumbent yang ditulis oleh Ristian (2016) menggambar kan rawannya kekuasaan politik calon incumbent atau petahana antara lain: (1) memanfaatkan birokrasi, (2) dapat meru sak nilai-nilai demokrasi yang ideal karena lebih mudah dan dekat untuk melakukan kecurangan. Pemanfaatan birokrasi dilakukan karena pada saat yang bersamaan 
calon petahana masih memegang kekuasaan yang sah dan legal secara hukum, sehingga jabatannya bisa menjadi power untuk melakukan kecurangan secara politis.

Rawannya penyalahgunaan kekuasaan dan kewenangan dalam skala lokal melalui pemilihan kepala daerah juga dikemukakan Tiran (2017). Ia mengung kapkan bahwa petahana adalah orang yang masih memilki pengaruh dalam pemilihan karena masih menjadi pemimpin sebelum pemilihan berikutnya. Penggunaan fasilitas negara merupakan modus yang paling sering dilakukan petahana. Dengan adanya kewenangan tersebut, sangat memungkinkan bagi petahana untuk membujuk, memengaruhi bahkan memerintah para bawahannya untuk berpihak dan memberikan dukungan untuk kepentingan petahana (Rahmat Hollyson MZ \& Sri Sundari, 2015, as cited in Rex Tiran, 2017). Keuntungan yang diperoleh petahana seperti disebutkan oleh Catherine Needham adalah kampanye permanen yang bisa dilakukannya, karena petahana sudah mempersiapkan diri untuk pemilihan jauh hari sebelum lawanlawannya dengan menggunakan program kerja pemerintah sebagai sarana kampanye secara langsung atau tidak langsung (Akhmad Farhan, 2017, as cited in Rex Tiran, 2017).

Penyalahgunaan kekuasaan dan kewenangan dalam praktik politik di tingkat lokal secara umum juga rentan terjadi dalam skala yang lebih luas, seperti dalam konteks pemilihan umum Presiden dan Wakil Presiden. Kecenderungan itu karena pola yang berbentuk linear dalam aspek politik hukum. Calon dari petahana dibiarkan melalui regulasi untuk terus berkuasa di saat mencalonkan diri kembali pada jabatan yang sama untuk periode kedua. Sementara calon non-petahana harus memulai upaya merebut kekuasaan dari titik nol. Disitulah sesungguhnya ketidakadilan yang kontra dengan demok rasi akan muncul.
Pakar Hukum Tata Negara Yusril Ihza Mahendra menyatakan Presiden petahana tidak perlu mundur bila kembali menjadi calon presiden. Menurutnya, bagi Presiden yang menjadi petahana tidak ada kewajiban untuk cuti atau mengundurkan diri. Pengaturan tentang keharusan mundur atau cuti itu tidak ada di dalam UU Nomor 7 Tahun 2017 tentang Pemilihan Umum (Erwanti, 2018, Yusril: Presiden Tak Perlu Cuti atau Mudur Saat Nyapres Lagi, https://news.detik.com/berita /420 4480/yusril-presiden-tak-perlu-cuti-ataumundur-saat-nyapres-lagi, diakses 12 Oktober 2018). Mantan Ketua Mahkamah Konstitusi Mahfud MD mengatakan bahwa seorang presiden petahana tidak harus mundur jika mencalonkan diri lagi sebagai presiden. Namun hanya perlu cuti saat berkampanye (Ermansyah, 2018, Mahfud MD: Presiden Petahana Tak Harus Mundur Jika Mencalonkan Diri Lagi, https:// aku rat.co/news/id-311770-read-mahfud-mdpresiden-petahana-tak-harus-mundur-jika -mencalonkan-diri-lagi, diakses 12 Okto ber 2018). Hal itu sesuai dengan Pasal 170 UU Nomor 7 Tahun 2017 tentang Pemilihan Umum. Kewenangan yang besar bagi Presiden petahana untuk berkampanye dengan tetap wajib memperhatikan keberlangsungan tugas penyelenggaraan negara. Bila dilihat dari regulasi, ada pengecualian bagi pejabat negara dengan jabatan tertentu untuk tidak mengundur kan diri dari jabatannya bila dicalonkan dan/ atau mencalonkan diri sebagai calon Presiden dan calon Wakil Presiden, seperti Presiden, Wakil Presiden, Pimpinan dan Anggota MPR, Pimpinan dan anggota DPR, Pimpinan dan Anggota DPD, Gubernur, Wakil Gubernur, Bupati, Wakil Bupati, Walikota, dan Wakil Walikota. Cuti berkam panye tidak banyak memberikan efek untuk menempatkan porsi yang sama dan adil dalam praktik demokrasi kepada seluruh calon, tetapi hanya bagian dari administratif prosedural semata.

Bias antara menjalankan tugas negara dan kampanye politik dalam 
konteks politik hukum dianggap sah dan legal, karena aturan-aturan tersebut secara jelas dinyatakan dalam suatu undangundang. Persoalannya, bila dilihat dalam perspektif demokrasi dalam konteks persaman hak setiap warga negara (termasuk juga pejabat negara), maka regulasi dengan mengkhususkan atau mengistimewakan pejabat negara (yang juga bagian dari elite politik), adalah suatu ketidakadilan. Hal semacam itu tentu bisa merusak tatanan proses demokrasi prosedural melalui kontestasi perebutan kekuasaan antarcalon Presiden dan Wakil Presiden.

Gagasan Maswadi Rauf dalam (Mufti \& Naafisah, 2013) menggambarkan tentang konsep kebebasan dan persamaan di antara sesama manusia melahirkan persyaratan yang ditekankan pada individu, persetujuan sebagai dasar dalam hubungan antarmanusia, persamaan manusia, keragaman, hak suara yang luas, serta kebebasan berbicara dan berkumpul. Persamaan politik (political equality) perlu dipertimbangkan bagi masa depan demokrasi Indonesia untuk menempatkan keadilan dan persa maan dalam setiap kontestasi politik secara periodik. Di samping akan menjaga kelangsungan proses demokrasi prosedu- ral melalui pemilihan umum secara kompetitif, rakyat bisa menilai bahwa proses demokrasi benar-benar dijalankan secara jujur dan adil melalui suatu regulasi hukum.

Dalam menyelenggarakan hak-hak politik secara efektif, cara terbaik untuk membatasi kekuasaan pemerintah adalah dengan konstitusi. Konstitusi itu menjamin hak-hak politik dan menjalankan pembagian kekuasaan negara sedemikian rupa sehingga kekuasaan eksekutif diim- bangi oleh kekuasaan parlemen dan lembagalembaga hukum. (Mufti \& Naafisah, 2013). Untuk itu diperlukan suatu desain substansi dan norma-norma yang adil dalam konstitusi politik, khususnya dalam penyelenggaraan pemilu agar political equality menjamin hak-hak rakyat sebagai pemegang kedaulatan rakyat dan para aktor politik yang berkontestasi dalam pemilihan Presiden dan Wakil Presiden.

Pembatasan kekuasaan pemerintah secara konstitusi bisa mewujudkan rasa keadilan kepada semua pihak yang sedang berkontestasi dalam pemilihan umum. Pembatasan ini bisa diartikan secara luas agar pemerintah yang sedang berkuasa tidak menggunakan kekuasaannya untuk menyalahgunakan wewenang yang dimilikinya. Kegaduhan dan kecurigaan politik tidak perlu terjadi apabila dibuat suatu regulasi hukum melalui proses politik hukum yang secara adil mengatur mekanisme pejabat negara yang akan menjadi calon Presiden dan /atau Wakil Presiden. Bentuk pembatasan tersebut adalah dengan meninjau kembali aspekaspek hukum sebagai landasan formal dan konstitusional agar perwujudan prinsip keadilan dalam implementasi demokrasi tercapai.

Dalam konteks regulasi hukum di Indonesia, UUD RI Tahun 1945 hanya menjelaskan bahwa jabatan Presiden dan Wakil Presiden selama lima tahun dan dapat dipilih kembali dalam jabatan yang sama untuk satu kali masa jabatan. Sementara mekanisme calon Presiden dan Wakil Presiden dari petahana menurut UU Nomor 7 Tahun 2017 Pasal 170 tidak dikecualikan dari pengunduran diri. Regulasi ini secara substansif sangat rawan terhadap kepentingan politik petahana dalam menggunakan kekuasaannya untuk kepentingan tertentu guna memenangkan pemilihan umum. Akan ada bias kepentingan ketika Presiden yang sedang berkuasa sekaligus berstatus Calon Presiden. Ia bisa berkampanye tanpa kampanye. Artinya, calon presiden dari petahana dengan kekuasaan yang masih melekat pada dirinya, cenderung menggunakannya untuk kepentingan politik jangka panjang, atau secara legalformal dan konstutusional menggunakan kekuasaan yang dimilikinya untuk berusaha menjegal calon Presiden dan 
Wakil Presiden lainnya.

Berpijak dari landasan realitas tersebut dalam praktiknya dewasa ini demokrasi Indonesia sedang mengarah kepada demokrasi substansif. Inti dari demokrasi substansif bermuara kepada kesejahteraan dan keadilan. Dalam tataran demokrasi prosedural yang sedang berlangsung, melalui kandidasi calon Presiden dan Wakil Presiden RI 20192023, maka haruslah menjunjung tinggi nilai-nilai demokrasi yang adil; adil bagi semua calon yang sedang berkompetisi memperebutkan suara rakyat, adil dalam proses implementasi demokrasi prosedural menuju demokrasi substantif.

Kekuasaan tidak bisa dimanfaatkan untuk kepentingan politik tertentu, karena ketika bias kekuasaan terjadi, maka nilainilai demokrasi akan terciderai, meskipun diatur melalui landasan hukum yang sah dan konstitusional. Akan tetapi, karena regulasi merupakan produk yang lahir melalui mekanisme politik hukum, sebuah regulasi yang bertentangan dengan nilainilai dan prinsip demokrasi tetap bisa untuk ditinjau ulang. Dalam konteks demokrasi di Indonesia, penerapan regulasi yang adil bagi semua calon Presiden dan Wakil Presiden akan bisa memangkas ketidakadilan, penyalahgunaan kekuasaan dan kewenangan, sehingga apabila terjadi pelanggaran pemilu yang dilakukan oleh setiap calon, semuanya bisa ditindak dengan adil tanpa ada intervensi dari pihak manapun, termasuk pemerintah.

Untuk mengisi kekosongan kepemim pinan seperti yang dikemukakan Yusril Ihza Mahendra maupun Mahfud MD, deregulasi UUD 1945 dan UU Pemilu secara prinsipil sangat diperlukan. Aturan main agar tidak terjadi kekosongan kepemimpinan di tingkat RI 1 dan 2, bisa dengan menyederhanakan penunjukan, pengangkatan serta pelantikan pemimpin/ presiden pengganti sampai habis masa jabatan presiden sebelumnya, yang berasal dari partai politik atau gabungan partai politik yang mengusulkan presiden yang maju kembali menjadi calon presiden, dalam waktu yang singkat.

\section{SIMPULAN}

Undang-Undang Dasar 1945 memberikan kesempatan bagi rakyat untuk menjadi Presiden dan Wakil Presiden selama dua periode atau dua kali masa jabatan. Meski kesempatan tersebut baru terbatas melalui partai politik sebagai "kendaraan" untuk mencalonkan diri. Akan tetapi, UUD 1945 tidak mengatur pejabat yang akan mencalonkan diri kembali untuk kedua kalinya secara berturut-turut harus mundur dari jabatannya sebagai Presiden atau Wakil Presiden. Meskipun UndangUndang Nomor 7 Tahun 2017 mengecualikan sejumlah pejabat negara untuk mundur apabila menjadi calon Presiden dan Wakil Presiden.

Secara legal-formal saat ini sah secara konstitusional. Namun bila kita meman dang pada hakikat demokrasi, maka akan ada ketidakadilan antara calon dari petahana dengan yang bukan petahana. Ada bias kepentingan, khususnya bagi calon dari petahana yang karena kekua saan dan kewenangannya yang sangat luas, sehingga diperlukan upaya untuk merekon struksi kembali produk hukum melalui jalan politik hukum. Hal itu dimaksudkan semata-mata untuk menjunjung tinggi asas persamaan dalam hukum, dan asas keadilan sehingga kontestasi politik dalam peralihan kepemimpinan benar-benar berkualitas dan tanpa menyiratkan peman faatan kepentingan melalui suatu jabatan untuk kepentingan politik. Keadilan berdemokrasi akan bisa dinilai apabila instrumen seperti regulasi yang mengaturnya diterapkan secara adil tanpa pengecualian.

Deregulasi UUD 1945 dan UU tentang Pemilihan Umum merupakan langkah korektif untuk semakin menjadikan demokrasi di Indonesia menerapkan prinsip dan nilai demokrasi yang setara, tanpa memberikan keistimewaan kepada 
warga negara tertentu. Relasi demokrasi harus dipandang secara holistik, dengan pembatasan kekuasaan serta mekanisme politik hukum berupa regulasi yang berkeadilan dan tidak memberlakukan keistimewaan tertentu kepada calon dari petahana. Disitulah sesungguhnya kekhawatiran ucapan Lord Acton (1887) dalam Rosenblatt (2012), power tends to corrupt and absolute power corrupts absolutely.

\section{DAFTAR PUSTAKA}

Ali (2009), MK Tolak Permohonan Capres Independen, diunduh di https://www.hukumonline.com/berita/bac a/hol21216/mk-tolak-permohonan-capresindependen, 12 Oktober 2018

Budiardjo, M (2004). Dasar-Dasar Ilmu Politik. Jakarta: Penerbit Gramedia

Budiyanto (2003). Dasar-Dasar Ilmu Tata Negara untuk Kelas 3. Jakarta: Penerbit Erlangga

Ekarista R.P (2018). Bawaslu: Gerakan '2019 Ganti Presiden' dan 'Jokowi 2 Periode' Tak Bisa Disebut Aktivitas Kampanye, diunduh di http://kaltim.tribunnews.com/2018/08/31 /bawaslu-gerakan-2019-ganti-presidendan-jokowi-2-periode-tak-bisa-disebut-akti vitas-kampanye, tanggal 14 Oktober 2018

Ermansyah, D (2018). Mahfud MD: Presiden Petahana Tak Harus Mundur Jika Mencalonkan Diri Lagi, diunduh di https://akurat.co/news/id-311770-readmahfud-md-presiden-petahana-tak-harusmundur-jika-mencalonkan-diri-lagi, tang gal 12 Oktober 2018

Erwanti, M.O (2018). Yusril: Presiden Tak Perlu Cuti atau Mudur Saat Nyapres Lagi, diunduh di https://news.detik.com/berita/4204480 /yusril-presiden-tak-perlu-cuti-atau-mun dur-saat-nyapres-lagi, tanggal 12 Oktober 2018

Fazli, A.Z (2018), Istana Sebut Gerakan 2019 Ganti Presiden Makar, diunduh di http://news.metrotvnews.com/hukum/Gb mj1nyk-istana-sebut-gerakan-2019-gantipresiden-makar, tanggal 14 Oktober 2018

Hajati, S. Winarsi, S. Sekarmadji, A \& Moechthar, 0 (2017). Buku Ajar Politik Hukum Pertanahan. Surabaya: Airlangga University Press
Labolo, M \& Teguh I. 2017. Partai Politik dan Sistem Pemilihan Umum di Indonesia: Teori, Konsep dan Isu Strategis. Jakarta: Penerbit Rajawali Pers

Linz, J.J \& Stepan, A (1996). Toward Consolidated Democracies. Journal of Democracy, 7(2): 14-33

Mahfud, MD. (2017). Politik Hukum di Indonesia. Jakarta: Penerbit Rajawali Pers

Mufti, M. (2013). Teori-Teori Politik. Bandung: CV Pustaka Setia

Mufti, M \& Durrotun, N.D. (2013). Teori-Teori Demokrasi. Bandung: CV Pustaka Setia

Peraturan Komisi Pemilihan Umum Nomor 32 Tahun 2018

Purnamasari, N (2018). Jokowi Buka Suara Soal Harga Premium yang Batal Naik, diunduh di https://finance.detik.com/energi/d-42549 94/jokowi-buka-suara-soal-harga-premi um-yang-batal-naik, tanggal 14 Oktober 2018

Rahadian, A (2018), Inilah Peta Partai Pengusung Capres dan Cawapres Pemilu 2019, diunduh di https://www.cnbcindone sia.com/news/20180810195720-16-28087 /inilah-peta partai-pengusung-capres-cawa pres-pemilu-2019, tanggal 12 Oktober 2018

Rahmadhani (2018). 10 Kepala Daerah di Sumbar Deklarasi Dukung Jokowi, diunduh di https://regional.kompas.com/read/2018/0 9/19/08113981/10-kepala-daerah-di-sum bar-deklarasi-dukung-jokowi, tanggal 14 Oktober 2018

Ristian, A. (2016). Demokrasi dan Kekuasaan Politik Calon Incumbent. Jurnal Ilmu Pemerintahan: Kajian Ilmu Pemerintahan dan Politik Daerah, 1(1):189-202

Rosenblatt, V.A. (2012). How Does Power Corrupt? The Way Individual And Institutional Support of Social Hierarchies Influences Unethical Behavior. Disertasi. The Graduate Division of The University of Hawaii at Manoa.

Sarwono, J. (2006). Metode Penelitian Kuantitatif dan Kualitatif. Yogyakarta: Graha Ilmu

Tiran, R. (2017). Kemenangan Petahana dan Demokrasi Lokal dalam Pilkada Kabupaten Kupang Tahun 2013. Tesis. Universitas Airlangga

UUD RI Tahun 1945

Undang-Undang Nomor 7 Tahun 2017 tentang Pemilihan Umum

Wahidin, S. (2017). Politik Penegakan Hukum di Indonesia. Yogyakarta. Pustaka Pelajar. 